by Christine J. Edgoose

\title{
The Amadeus Basin, central Australia
}

Northern Territory Geological Survey, PO Box 8760, Alice Springs, NT 0871, Australia. E-mail: christine.edgoose@nt.gov.au

The Amadeus Basin of central Australia has a depositional history spanning the Neoproterozoic to the Devonian/Carboniferous. It was initiated as part of the Neoproterozoic Centralian Superbasin, which formed in an intracratonic setting related to the break up of Rodinia. Sedimentation continued until the 580-540 Ma Petermann Orogeny, coinciding with the assembly of Gondwana, which resulted in the fragmentation of the superbasin into separate intracratonic basins. The Petermann Orogeny was focused in the Musgrave Province and the southern part of the Amadeus Basin, and involved significant $\mathrm{N}$-directed shortening on largescale structures that involved both the basement and the overlying Neoproterozoic sedimentary rocks. It significantly transformed the basin architecture, with the development of major basin features that controlled subsequent sedimentation. Deposition of Paleozoic successions was largely concentrated in sub-basins and troughs in the $N$ of the basin, where up to $14 \mathrm{~km}$ is preserved. Minor events or uplifts punctuated this depositional history and account for local disconformities and absent sections. The 450-300 Ma Alice Springs Orogeny was a multi-phase, intracratonic event concentrated in the Arunta Region and the northern part of the Amadeus Basin. Like the earlier Petermann Orogeny, the Alice Springs Orogeny involved both basement and basin sedimentary rocks, but with overall $S$-directed movement. Synorogenic sedimentation accompanied Mid-Late Devonian uplift, with Late Devonian-Carboniferous basin inversion terminating sedimentation, and folding the youngest successions.

The Amadeus Basin has known reserves of $U$, minor historic and recent $A u$ production, and is prospective for base metals, especially $\mathrm{Cu}$, and phosphate. The Ordovician succession supports commercial gas production, and the Neoproterozoic succession is considered prospective for oil and gas.

\section{Introduction}

The Amadeus Basin is a large (c. 170,000 $\mathrm{km}^{2}$ ) elongate intracratonic Neoproterozoic-Devonian basin that extends c. $800 \mathrm{~km}$
E-W and a maximum of $300 \mathrm{~km} \mathrm{~N}-\mathrm{S}$ in central Australia (Figure 1). It overlies Paleo-Mesoproterozoic basement of the Musgrave Province to the $\mathrm{S}$ and Arunta Region to the N, and is overlain by the late Paleozoic Pedirka Basin and Mesozoic Eromanga Basin in the SE, and by the Paleozoic stratigraphy of the Canning Basin to the W. The present-day Amadeus Basin is a structural remnant of a broad, shallow basin - it has been significantly tectonically modified during two major intracratonic orogenic events: the 580540 Ma Petermann Orogeny and the 450-300 Ma Alice Springs Orogeny.

The early history of the Amadeus Basin is as part of the Neoproterozoic Centralian Superbasin (Walter et al., 1995), which also encompassed the Officer, Ngalia, Georgina, and Murraba basins (Shaw et al., 1991; Walter et al., 1995), and probably several smaller basins in Western Australia (Figure 2). Formation of the Centralian Superbasin coincided with NE-SW-directed intracratonic extension across the Rodinia Supercontinent, which eventually led to the breakup between North America and Australia at c. $830 \mathrm{Ma}$ (deVries et al., 2000). Walter and Veevers (2000) described this phase as Centralian 1. After the break up of Rodinia, sedimentation continued locally in the Centralian Superbasin until c. 750 Ma. In the Centralian 2 phase, renewed but localised sedimentation related to the 700-690 Ma Sturtian glaciation took place. Centralian 3 is associated with the younger Elatina (Marinoan) glaciation. Sedimentation in the Centralian Superbasin was terminated by the 580-540 Ma Petermann Orogeny, which coincided with the final stages of the assembly of Gondwana (de Vries et al., 2000), but continued locally in the now separated basins, for example in the northern part of the Amadeus Basin.

Korsch and Lindsay (1989) and Lindsay and Korsch (1991) recognised three main stages of basin evolution. Stage 1 was a longlived extensional-thermal relaxation (sag) event (c. 900-590 Ma). In the SW of the basin, Stage 1 sediments are underlain by a rift sequence (bimodal volcanics and associated sedimentary rocks (e.g., Close et al., 2004; Edgoose et al., 2004). The relationship of this rift succession to the initiation and early evolution of the Amadeus Basin is equivocal, as the rift sequence is c. $150 \mathrm{Ma}$ older than the Stage 1 sediments (sag phase). Such a time gap suggests the rift and sag may not be related (Shaw, 1991). However, it is also possible that a significant time break occurs at a disconformity within the sag phase sediments, and that the deposition of sag phase sediments commenced soon after rifting ceased (A. Camacho, per. comm., 2011). Stage 2 (c. 580-450 Ma) comprised an early compressive event (Petermann Orogeny) then extension followed by a thermal relaxation event and resulted in shallow-marine to terrestrial deposition across the basin. Stage 3 (c. 450-300 Ma) was the final phase of basin evolution and was a dominantly compressional phase (Alice Springs Orogeny). Events relating to this stage account for most of the obvious structures (folds, domes and thrusts) evident in the present-day surface geology (Figure 3). 


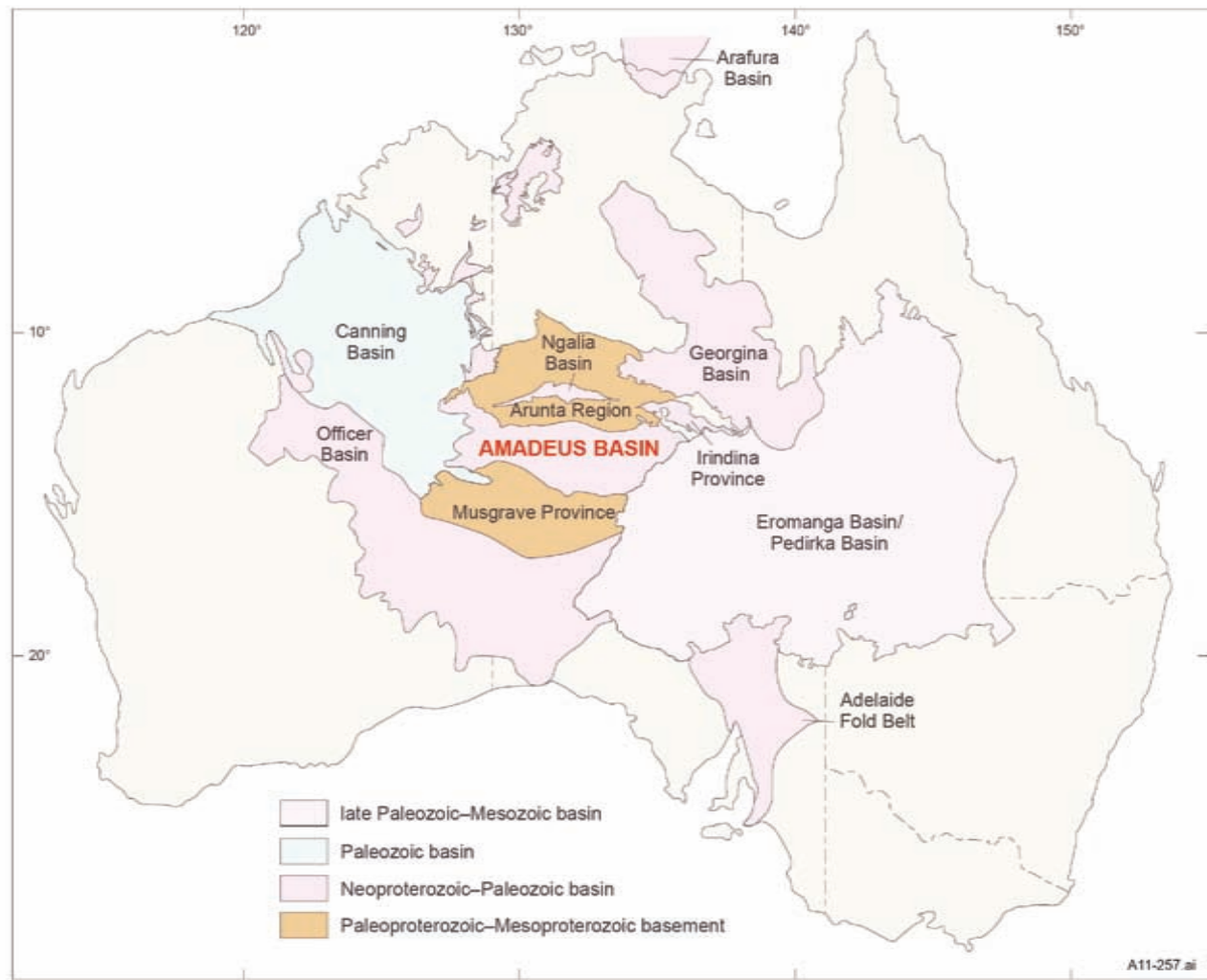

Figure 1 Location of Amadeus Basin and surrounding tectonic regions. zircon data points to different source areas for the two basins (Haines and Wingate, 2007). The Amadeus Basin shows evidence of having been open to the $\mathrm{E}$ and sourced material from eastern Australia. Marine sedimentation ceased at the end of the Ordovician in response to broad, regional uplift. From this time to the Early Devonian, only limited deposition occurred in the basin, in aeolian and lesser fluviatile systems. The Silurian was largely a period of hinterland erosion, followed by fluvio-lacustrine to paralic conditions in parts of the basin in the late Early Devonian. The middle-late Devonian is characterised by an upward-coarsening fluvial system, deposited in response to uplift related to the Alice Springs Orogeny, and sedimentation culminated in the Late Devonian/early Carboniferous as a result of final orogenic processes and basin inversion. Permian glaciation in the area suggests that highlands persisted until this time, and that the area was at relatively high paleolatitudes.

The units of the Amadeus Basin are discussed in more detail below (see also Figure 4).

\section{Neoproterozoic}

\section{Cryogenian: Supersequence 1}

A sequence stratigraphic analysis has identified 4 supersequences in the Neoproterozoic stratigraphy of the Amadeus Basin (Walter et al., 1995). Supersequence 1 forms part of the initial sag phase, equivalent to Stage 1 basin evolution of Lindsay and Korsch (1991) and Interval 1 of Shaw (1991). The sequence comprises a relatively thin, basal clean sand sheet deposited in intertidal and fluviatile environments (Heavitree and Dean quartzites), followed by a thicker succession of marine carbonate rocks, fine siliciclastic sedimentary rocks and evaporites (Bitter Springs Formation and Pinyinna beds).

The characteristics of the Heavitree and Dean quartzites imply an abundant supply of sediment deposited in a high-energy shelf-like environment. Sedimentological and stratigraphical analyses by Lindsay $(1993,1999)$ show that quartz sandstone sedimentation occurred in a shallow, low-gradient ramp setting. Detrital zircon data for the Heavitree Quartzite suggests a maximum deposition age of 1050-1000 Ma (Zhao et al., 1992), with detrital zircon age data indicating a source dominated by the Arunta Region. Maidment et al., (2007) provided the youngest zircon age at $1.12 \mathrm{Ga}$, probably sourced from the Musgrave Province.

The Bitter Springs Formation comprises three members consisting of crystalline dolomitic limestone, dolostone and limestone, dololutite, dolarenite, calcarenite, siltstone, gypsiferous siltstone, sandstone, halite and evaporites, with a thin, and probably discontinuous, spilite 


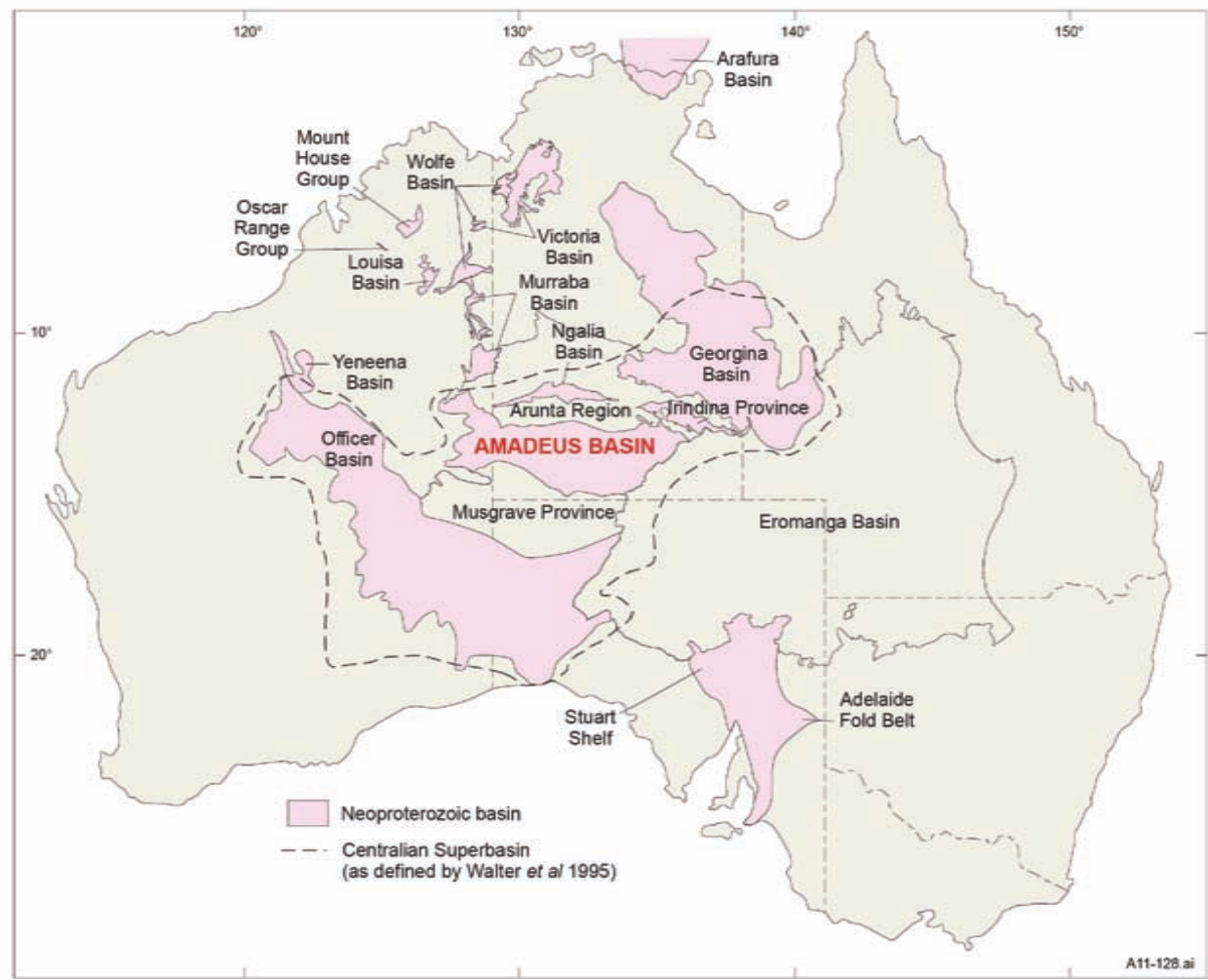

Figure 2 Centralian Superbasin (after Walter et al., 1995).

unit within the succession. The Pinyinna beds are the metamorphosed equivalent of the Bitter Springs Formation in the SW of the Basin. The age of the Bitter Springs Formation is interpreted to be c. 820 Ma, from the spilite layers, which have geochemical affinities with dykes dated at c. 800 Ma using Sm-Nd mineral isochrons (Zhao et al., 1994) and at $824 \pm 4$ Ma by U-Pb dating of baddelyite (Glikson et al., 1996). The upper part of the Bitter Springs Formation contains the Cryogenian stromatolite assemblage Acaciella australica, which is older than $802 \pm 10 \mathrm{Ma}$ and younger than c. $825 \mathrm{Ma}$ in the Officer Basin in WA (Grey, 2005).

The Areyonga Movement is expressed as an unconformity between the Bitter Springs Formation and the overlying Areyonga Formation in the NE of the basin. However, it is possible that this unconformity is related to halotectonic processes rather than to a discrete tectonic event (Kennedy, 1993).

\section{Mid-late Cryogenian: Supersequence 2}

Supersequence 2 equates with the 700-690 Ma Sturtian glaciation, and comprises the Areyonga and Aralka formations and the equivalent unit in the southern part of the basin, the Inindia beds, and in the western part of the basin, the Boord Formation. The Areyonga Formation is formed predominantly of diamictite (tillite) of variable composition and texture, but includes thin interbeds of sandstone, conglomerate, shale and siltstone, and dolostone. This glaciogenic succession shows marked lithological variation from massive, indurated diamictite/conglomerate to carbonaceous siltstone/shale, feldspathic sandstone, and rarer dolostone in the middle and at the top of the succession. The Aralka Formation is largely siltstone and shale, but includes dolostone and calcarenite that is in part pisolitic and stromatolitic, and a dominantly clastic unit, characterised by pebbly and sandy calcarenite and festoon-bedded sandstone. The dolostone contains the columnar stromatolite Tungussia inna Walter (Walter et al., 1995). The Inindia beds comprise a generally thick but variable unit of sandstone with lesser siltstone, chert and jasper, tillite and dolostone that is relatively poorly exposed in the SW and south-central parts of the basin. The Boord Formation contains two glacial units, several disconformities, and significant pre- and post-glacial intervals (Haines et al., 2010).

\section{Late Cryogenian-early/mid Ediacaran: Supersequence 3}

Supersequence 3 is associated with the c. 650-635 Ma Elatina glaciation. It comprises the Olympic Formation, Pioneer and Gaylad sandstones, the Pertatataka Formation and Julie Formation in the central-northern part of the basin. The newly proposed Neoproterozoic stratigraphic correlations of Haines et al., (2010) would suggest that the Inindia beds in the southern part of the basin correlate with both Supersequence 2 and 3 , and the overlying Winnall beds, which were formerly considered as Supersequence 3, are now considered to be younger.

The Olympic Formation consists of lenticular units of sandstone, siltstone conglomerate, diamictite, shale and an upper 'cap' dolostone, and is up to $190 \mathrm{~m}$ thick. The Pioneer Sandstone (Priess et al., 1978) is a shallow-marine to tidal unit, confined to the central-northern part of the Amadeus Basin. It consists of cross-bedded, medium- to coarsegrained feldspathic and arkosic sandstone, grading up into pink-grey dolostone with red chert nodules. The Pioneer Sandstone is interpreted to be an intertidal periglacial, or glacial outwash facies that correlates with diamictite of the Olympic Formation (Preiss et al., 1978; Walter et al., 1995), although this correlation has been questioned (Lindsay, 1989; Field, 1991). The type section for the Gaylad Sandstone consists of quartz sandstone, lithic sandstone, subarkose, orthoconglomerate, and rare debris-flow diamictite. At its type section, the Pertatataka Formation is c. $350 \mathrm{~m}$ thick, and is made up of $320 \mathrm{~m}$ of red and green siltstone and shale, with flaser bedding and small-scale cross laminations, overlain by $1.5 \mathrm{~m}$ of grey, medium-grained feldspathic silicified sandstone, and $30 \mathrm{~m}$ of red siltstone with sandstone laminae (Prichard and Quinlan, 1962). U-Pb SHRIMP dating of detrital zircons by Maidment et al. (2007) gave a youngest concordant age of c. $807 \mathrm{Ma}$, significantly older than the inferred depositional age of c. $575 \mathrm{Ma}$.

\section{Late Neoproterozoic-Cambrian: Supersequence 4}

The Petermann Orogeny (580-540 Ma) was a crustal-scale, bivergent intracratonic event localised in the Musgrave Province and in overlying Neoproterozoic stratigraphy of the Amadeus and Officer basins (Scrimgeour and Close, 1999; Close et al., 2004; Edgoose et 


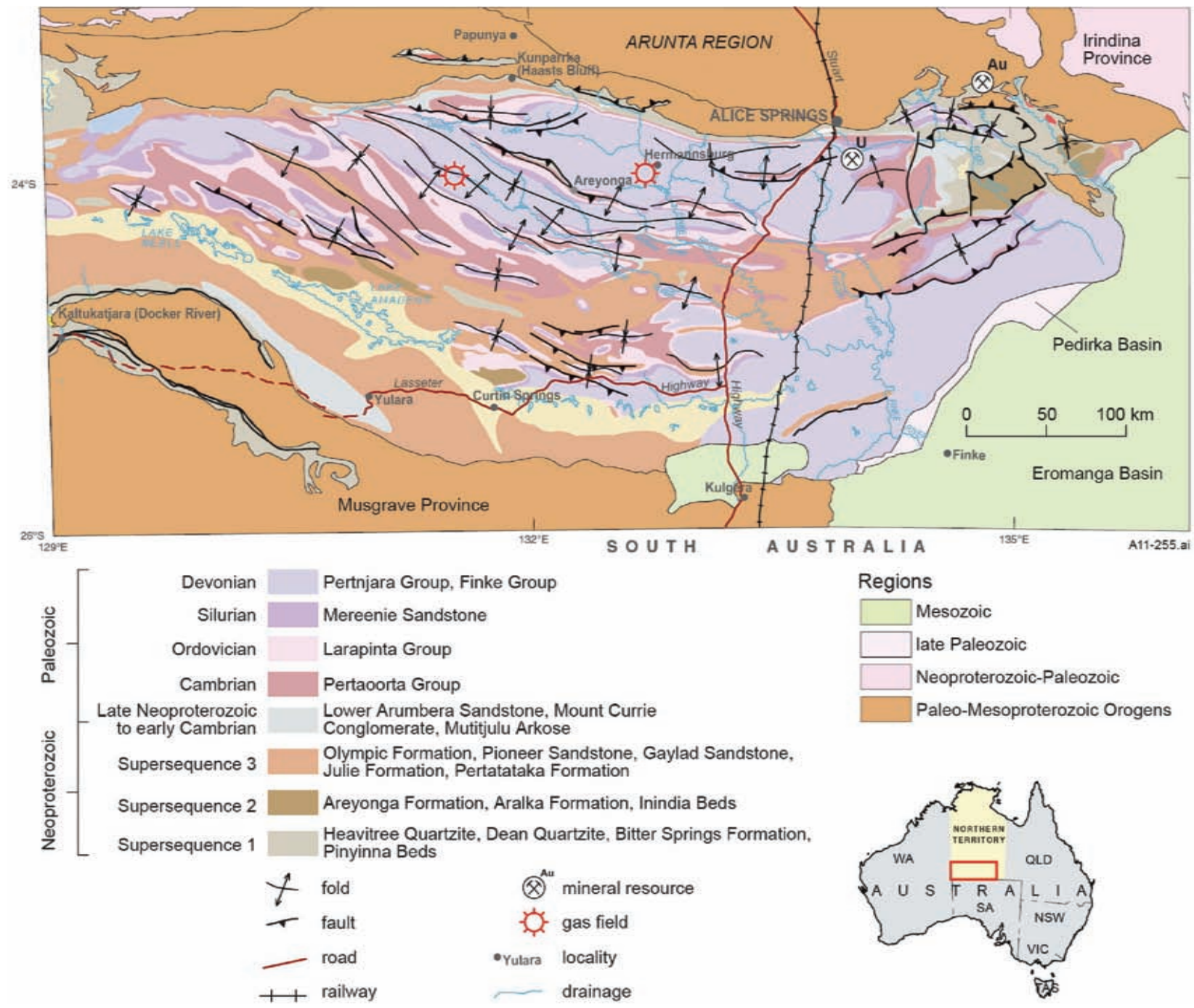

Figure 3 Generalised geology and major structures of the Amadeus Basin, Northern Territory.

al., 2004). In the Amadeus Basin, the Petermann Orogeny is traditionally considered to have resulted in only limited foreland basin development, despite N-vergent shortening of c. $100 \mathrm{~km}$ and thickening that buried the basal basin succession to depths of $20 \mathrm{~km}$ (Flottmann et al., 2004). However, revised stratigraphic correlations now suggest that up to $6 \mathrm{~km}$ of sediments in the $\mathrm{W}$ and $\mathrm{SW}$ of the basin are synchronous with the Petermann Orogeny (Haines et al., 2010).

Within the basal Amadeus Basin succession, progressive deformation during the Petermann Orogeny is recorded in at least three phases of folding, with the earlier phases involving both basement and sedimentary rocks (Scrimgeour et al., 1999; Edgoose et al., 2004). Large detachment zones exhumed interleaved basement rocks and sedimentary rocks of Supersequence 1 from mid crustal levels. North-vergent thrusts repeat the basal Amadeus succession $\mathrm{N}$ of a large-scale basement wedge, with significant back thrusting of younger (Supersequence 2 and 3) Neoproterozoic sedimentary rocks to the $\mathrm{S}$ accommodating the shortening.

The Amadeus Basin suffered major disruption during the Petermann Orogeny, resulting in fragmentation of the basin architecture, with the development of large sub-basins and troughs $\mathrm{N}$ of a central ridge, and a platform in the $\mathrm{S}$ (Figure 5). Depositional loci moved northwards and sedimentation was concentrated in these major depocentres. A total of 2,800 $\mathrm{m}$ of clastics were shed into the Carmichael Sub-basin and 1,500 $\mathrm{m}$ into the Missionary Plains Trough (Lindsay, 1993; Ambrose, 2006). Paleozoic sedimentation was apparently restricted, or for considerable time periods absent, in the southern part of the basin.

The late Neoproterozoic-Cambrian succession in the northern part of the Basin (Pertaoorta Group) is stratigraphically variable from $\mathrm{E}-\mathrm{W}$, and comprises many named units that represent facies changes across the geographic area of distribution. The Group is dominated by carbonate rocks in the $\mathrm{E}$, and by siliciclastic successions in the W. The oldest formation, the Arumbera Sandstone, is divided into two depositional successions of upward-coarsening siltstone and sandstone (Lindsay, 1987; Kennard and Lindsay, (1991) - the lower is Neoproterozoic whereas the overlying formations are all early Cambrian in age. The upper Arumbera Sandstone has yielded more than thirty different ichnospecies (Kennard in Kennard and Nicoll, 1986; Shergold, 1986; Shergold et al., 1991). The lower Arumbera Sandstone has yielded specimens of the soft-bodied Ediacarian fauna (metazoan body fossils).

On the southern platform, the newly proposed correlations of Haines et al. (2010) indicate that the Carnegie Formation, Sir Frederick Conglomerate, Ellis Sandstone and Maurice Formation of the far W and SW, and the Winnall beds of the SW and south-central parts of 


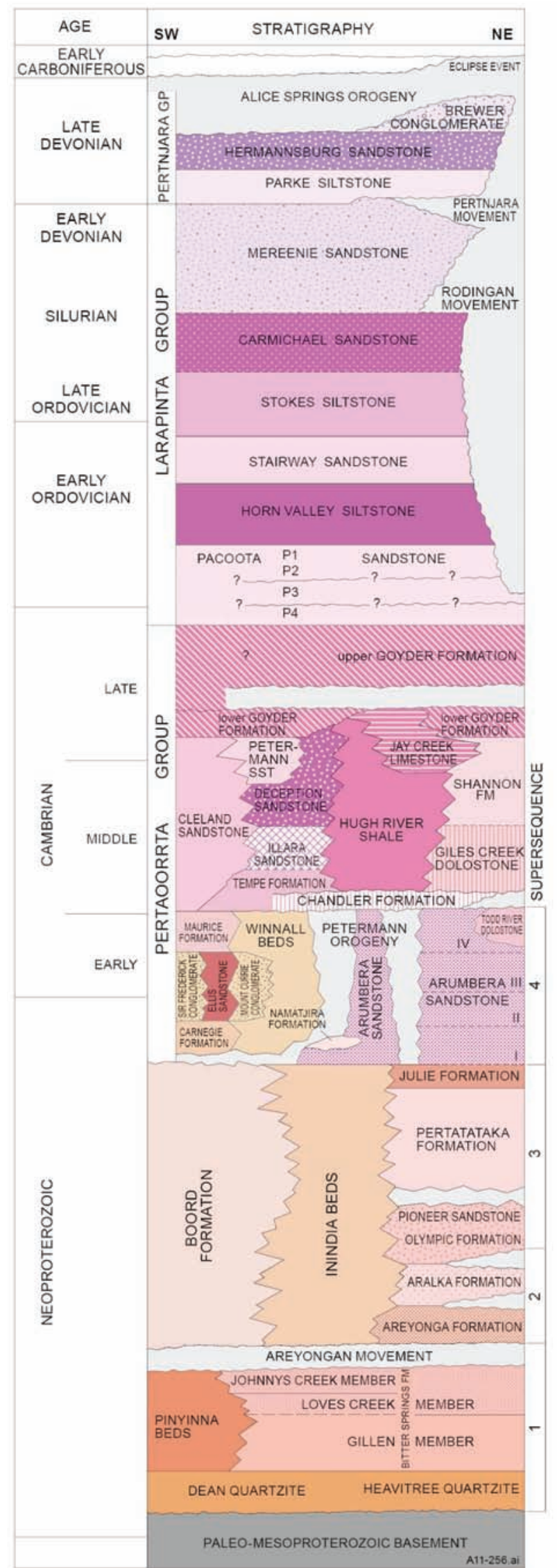

Figure 4 Stratigraphy of the Amadeus Basin (modified from Marshall et al., 2007; Haines et al., 2010). The supersequence scheme of Walter et al., (1995) is shown on the right. the basin are correlatives of the Arumbera Sandstone, rather than correlatives of the late Neoproterozoic Supersequence 3. Coarse clastic sediments of the Mount Currie Conglomerate and Mutitjulu Arkose are correlated with the Sir Frederick Conglomerate and Ellis Sandstone, and were deposited in localised foreland basins in the hinterland of the emergent basal Amadeus succession and Musgrave Province basement during the Petermann Orogeny. These deposits reflect proximal and more distal high-energy fluvial environments of broad shallow channels or sheet floods. In the south-central part of the basin, minor locally developed successions that are interpreted to be laterally equivalent to the Mount Currie Conglomerate represent restricted molasse deposits related to paleohighs created during the Petermann Orogeny.

\section{Ordovician}

The potential for oil and gas in the Ordovician succession was recognised early on, and consequently, it has been the focus of more study than most of the other successions in the basin.

The Larapinta Group comprises 5 constituent formations. The Pacoota Sandstone comprises four units of shallow-marine sandstone (Williams et al., 1965). The Horn Valley Siltstone comprises thinly bedded organic rich shale and siltstone, with bedded nodular limestone abundant in some intervals (Shergold, 1986). It has an abundant and well preserved faunal and floral assemblage, which includes trilobites, brachiopods, pelecypods, nautiloids, ostracods, conodonts, chitinozoa, acritarchs, graptolites and gastropods, and simple spores and algae (Shergold, 1986). Conodonts and trilobites indicate a late Early Ordovician (Floian) age (Cooper, 1981; Nicoll and Jones in Kennard and Nicoll, 1986). The Stairway Sandstone has an abundant fossil assemblage which indicates a strong marine influence in shallow subtidal and partly intertidal conditions (Cook, 1972), and includes local phosphorites The assemblage comprises trilobites, brachiopods, sponges, rostroconchs, gastropods, cephalopods, pelcypods, monoplacophorans, vertebrates, chitinozoans and acritarchs, which give an Early Ordovician (Dapingian or Dariwilian) age. U-Pb zircon data (Maidment et al., 2007) gives maximum deposition ages in the range 650-500 Ma. The Stokes Siltstone comprises a lower siltstone and limestone lithofacies, and an upper red and purple sandstone and shale lithofacies (Shergold, 1986). The formation contains relatively few fossils (Nicoll in Kennard and Nicoll, 1986), but includes gastropods, a brachiopod, a bryozoan, rostroconch molluscs and bivalve molluscs, nautiloid cephalopods, trilobites and conodonts (Shergold, 1986). The fauna indicate an Early Ordovician (Dapingian or Dariwilian) age. The Carmichael Sandstone comprises variable interbedded pale brown to redbrown sandstone, siltstone and mudstone, indicating a mixed depositional environment, comprising shallow-marine to possibly hypersaline and fluvial conditions (Owen in Kennard and Nicoll, 1986). The only recorded fossils are rare ichnofossils, including Cruziana.

The Rodingan Movement (Cook in Wells et al., 1970; Shaw, 1991; Bradshaw and Evans, 1988) presents as an unconformity between the Carmichael Sandstone and Mereenie Sandstone in the N and NE of the basin. It is interpreted to be a low-angle feature that cuts down to the NE, and probably coincided with the end of marine sedimentation in the basin.

The c. 490-480 Ma Larapinta Event was a high-grade tectonometamorphic event that affected Amadeus Basin sedimentary 


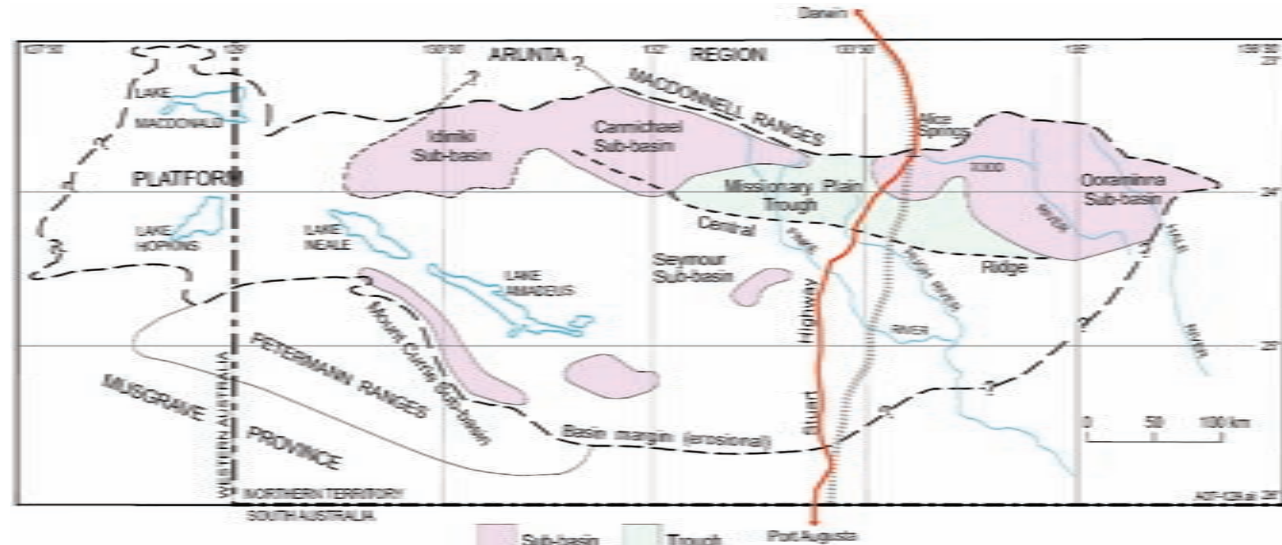

Figure 5 Architecture of the Amadeus Basin (from Marshall et al., 2007, after Lindsay and Korsch, 1991).

equivalents deposited in a deep trough (Irindina Province) to the NE of the basin (Mawby et al., 1998, 1999; Maidment et al., 2007). Rapid, deep burial and exhumation in an extensional setting affected this trough during the Larapinta Event, resulting in the exhumation of granulite-facies metasedimentary rocks. The Irindina Province is included in the Arunta Region as a result of its uniquely complex, high-grade tectonothermal history.

\section{Late Ordovician-Silurian}

The Mereenie Sandstone is one of the most widespread units of the basin (Owen in Kennard and Nicoll, 1986). Most of the lower part was deposited in a shallow-marine environment, which transitions to aeolian-fluvial environments for the upper part. Paleocurrent data suggest an E-SE-trending shoreline for the lower marine section, and sediment transport towards the $\mathrm{E}$ and $\mathrm{S}$ for the upper section (Owen in Kennard and Nicoll, 1986). U-Pb zircon data (Maidment et al., 2007) are dominated by ages in the range 630-490 Ma. There are few older grains, suggesting the Mereenie Sandstone was largely derived from the reworking of underlying units.

The Pertnjara Movement is expressed as an unconformity between the Mereenie Sandstone and Pertnjara Group, in the central-north and NE of the basin. It initiated deposition of the Pertnjara Group, and may have produced gentle folding or thrusting in the NE.

\section{Devonian-Carboniferous}

The Pertnjara Group consists of a series of lacustrine, braided and meandering fluviatile, and alluvial fan deposits, which accumulated on a S-thinning depositional wedge. Variations in the distribution, maturity and facies in the Pertnjara Group reflect successive tectonic pulses of the Alice Springs Orogeny, which were coincident with its deposition (Jones, 1991). Devonian fish fossils have been found and described from several localities (GilbertTomlinson, 1968; Young, 1974, 1985, 1988, 2005), with the fauna giving a Givetian-Frasnian age (Young, 1985). The Finke Group is a correlative of the Pertnjara Group in the southern part of the basin. Sediment source is dominantly from the Musgrave Province to the $\mathrm{S}$, with a later switch to the progressively emergent Arunta Region to the N (Jones, 1973).

The Alice Springs Orogeny (450-300 Ma) was a long-lived, multiphased, bivergent intracratonic event with its strongest effects in the northern part of the Amadeus Basin and the Arunta Region basement. Some of its earlier phases are recognised as discrete events (e.g., Pertnjara Movement, see above). It resulted in basin inversion and the cessation of Paleozoic deposition in the Amadeus Basin.

The Alice Springs Orogeny involved considerable crustal shortening $(50 \mathrm{~km}$ - Flottmann et al., 2004; 60-125 km - Haines et al., 2001). The former authors describe two phases of shortening: S-directed overthrusting of a basement wedge; and underthrusting that produced a large-displacement, N-vergent, passive back thrust in the $\mathrm{N}$ of the basin. Deformation related to the Alice Springs Orogeny accounts for most of the obvious structures (folds, domes and thrusts) in the present-day surface geology in the Amadeus Basin (Figure 3).

Haines et al. (2001) took a synorogenic sedimentological approach to assessing the distribution and timing of events associated with the Alice Springs Orogeny. The orogeny had a prolonged duration of $\mathrm{c}$. 150 million years (c. 450-300 Ma) with peaks of activity at 450-440 (Rodingan Movement), 390-375 and 340-320 (Eclipse Event) Ma. These episodes were also described by Bradshaw and Evans (1988), who also recognised spatial variation and divided the basin into several provinces with varied structural responses to the orogen as it progressed. The earliest phase of the Alice Springs Orogeny at c. $450-440 \mathrm{Ma}$ is also recorded in the Irindina Province and adjacent Arunta Region basement as extension on major shear zones. In the $\mathrm{NE}$ of the basin, the orogeny formed large, S-directed, basementcored nappes, which are characteristic of Alpine mountain belts and are generally not typical of intracratonic settings (Dunlap and Tessyier, 1995).

Isotopic and geological data indicate re-activation of major Proterozoic shear zones during the Alice Springs Orogeny (e.g., Shaw, 1991; Dunlap and Tessyier, 1995), for example the crustal scale Redbank Thrust Zone on the northern margin. Sedimentological and fission track dating data indicates the removal of a substantial thickness of younger strata from the northern part of the basin late in the Alice Springs Orogeny.

\section{Halotectonics}

The influence of halotectonics on the distribution of sedimentary rocks, structural styles and deformation has been recognised within the Neoproterozoic and early Paleozoic successions in various parts of the Amadeus Basin, but is best shown in the NE. It is generally associated with halite in the Neoproterozoic Bitter Springs Formation and to a lesser extent in the Cambrian Chandler Limestone. Kennedy (1993) reported the effects of diapiric growth on local facies and structure in late Neoproterozoic successions, where salt withdrawal led to normal faulting and syn-sedimentary thickening of adjacent units, as well as local unconformities on units flanking the diapiric structures. Marshall and Dyson (2007) interpreted Neoproterozoic and early Paleozoic sedimentation in the Amadeus Basin to have occurred dominantly in a series of salt nappe complexes and mini- 
basins, which were formed under the influence of gravity gliding, gravity spreading and salt withdrawal. They attribute many of the fold-thrust nappes previously ascribed to the Alice Springs Orogeny as having most likely formed during salt movement associated with Neoproterozoic sedimentation.

\section{Petroleum and Mineral Resources}

The Amadeus Basin has significant potential for further oil and gas discoveries. For a known producing basin, it is significantly underexplored. Up until 2006, the basin had 33 wells (one well per $5,000 \mathrm{~km}^{2}$ ) and 7,500 km of seismic data. Renewed exploration for petroleum has occurred in the basin more recently, with seismic acquisition and drilling taking place.

Five petroleum systems are described by Marshall (2004) and Marshall et al. (2007). These are 1 - Heavitree Quartzite/Gillen Member of the Bitter Springs Formation, 2 - Loves Creek Member of the Bitter Springs Formation-Pioneer Sandstone, 3 - Pertatataka Formation-Julie Formation, 4 - Arumbera Sandstone-Chandler Formation, and 5 - Larapinta Group. Currently, the only the latter, encompassing the Mereenie, Palm Valley and West Walker hydrocarbon occurrences (Figure 3), is a commercially productive petroleum system (Marshall, 2004).

The Amadeus Basin has undergone comparatively little exploration for mineral commodities. Mineral production in the Amadeus Basin is confined to minor historical and recent $\mathrm{Au}$ production from the Arltunga and Winnecke goldfields (Heavitree Quartzite) in the NE of the basin (Figure 3), and historic working of minor surficial $\mathrm{Cu}$ at a few locations in early Paleozoic stratigraphy in the north-central part. The Basin has known reserves of $U$ in Devonian stratigraphy S of Alice Springs (Figure 3; Lally and Bajwah, 2006), and recorded occurrences of base metals, manganese and phosphate (Edgoose, 2012).

\section{Acknowledgements}

The author thanks Peter Haines and Jon Clarke for their reviews which substantially improved the manuscript. T. Munson and D. Close are also thanked for their helpful comments on an earlier version of the manuscript. Kathy Johnston is thanked for the high quality figures. The author publishes with the permission of the Director, Northern Territory Geological Survey.

\section{References}

Ambrose, G.J., 2006, Northern Territory of Australia onshore hydrocarbon potential 2006: Northern Territory Geological Survey, Record 2006-003.

Bradshaw, J.D. and Evans, P.R., 1988, Palaeozoic tectonics, Amadeus Basin, central Australia: The APEA Journal, v. 28, pp. 267-282.

Close, D.F., Edgoose, C.J. and Scrimgeour, I.R., 2004, Hull and Bloods Range Northern Territory. 1:100,000 special geological series explanatory notes (first edition), 4748, 4848: Northern Territory Geological Survey, Darwin.

Cook, P.J., 1972, Sedimentological studies on the Stairway Sandstone of central Australia: Bureau of Mineral Resources, Bulletin 95.

Cooper, B.J., 1981, Early Ordovician conodonts from the Horn Valley Siltstone, central Australia: Palaeontology, v. 24, pp. 147-183.

de Vries, S.T., Pryer, L.L. and Fry, N., 2000, Evolution of Neoarchaean and Proterozoic basins of Australia: Precambrian Research, v. 100, pp. 3953.

Dunlap, J.W. and Tessyier, C., 1995, Palaeozoic deformation and isotopic disturbance in the southeastern Arunta Block, central Australia:
Precambrian Research, v. 71, pp. 229-250.

Edgoose, C.J., 2012, Amadeus and Warburton basins, in Ahmad, M. and Munson, T.J., (compilers), Geology and mineral resources of the Northern Territory: Northern Territory Geological Survey, Special Publication 5 (in press).

Edgoose, C.J., Scrimgeour, I.R. and Close, D.F., 2004, Geology of the Musgrave Block, Northern Territory: Northern Territory Geological Survey, Report 15.

Field, B.D., 1991, Parallic and periglacial facies and contemporaneous deformation of the Late Proterozoic Olympic Formation, Pioneer Sandstone and Gaylad Sandstone, Amadeus Basin, central Australia: Bureau of Mineral Resources, Geology and Geophysics, Bulletin 236, pp. 127-136.

Flottmann, T., Hand, M., Close, D.F., Edgoose, C.J. and Scrimgeour, I.R., 2004, Thrust tectonic styles of the intracratonic Alice Springs and Petermann orogenies, central Australia, in McClay, K.R. (ed), Thrust tectonics and hydrocarbon systems: AAPG, Memoir 82, pp. 538-557.

Gilbert-Tomlinson, J., 1968, A new record of Bothriolepis in the Northern Territory of Australia: Bureau of Mineral Resources, Bulletin 80, pp. 189-224.

Glikson, A.Y., Stewart, A.J., Ballhaus, C.G., Clarke, G.L., Feeken, E.H.J., Leven, J.H., Sheraton, J.W. and Sun, S-S. , 1996, Geology of the western Musgrave Block, central Australia, with particular reference to the maficultramafic Giles Complex: Australian Geological Survey Organisation, Bulletin 239.

Grey, K., 2005, Ediacaran palynology of Australia: Association of Australasian Palaeontologists, Memoir 31.

Haines, P.W. and Wingate, M.T.D., 2007, Contrasting depositional histories, detrital zircon provenance and hydrocarbon systems: Did the larapintine Seaway link the Canning and Amadeus basins during the Ordovician? in Munson, T.J. and Ambrose, G.J. (eds), Proceedings of the Central Australian Basins Symposium (CABS), Alice Springs, Northern Territory, 16-18 August, 2005: Northern Territory Geological Survey, Special Publication 2, pp. 36-51.

Haines, P.W., Hand M. and Sandiford, M., 2001, Palaeozoic synorogenic sedimentation in central and Northern Australia: a review of distribution and timing with implications for the evolution of intracontinental orogens: Australian Journal of Earth Sciences, v. 48, pp. 911-928.

Haines, P.W., Allen, H.J., Grey, K., 2010, Reassessment of the geology and exploration potential of the Western Australian Amadeus Basin, in GSWA 2010 Extended Abstracts: promoting the prospectivity of Western Australia: Geological Survey of Western Australia, Record 2010/2.

Jones, B.G., 1973, Sedimentology of the Upper Devonian to Lower Carboniferous Finke Group, Amadeus and Warburton basins, central Australia: Journal of the Geological Society of Australia, v. 20, pp. 273293

Jones, B.G., 1991, Fluvial and lacustrine facies in the Middle to Late Devonian Pertnjara Group, Amadeus Basin, Northern Territory, and their relationship to tectonic events and climate: Bureau of Mineral Resources, Bulletin 236, pp. 333-348.

Kennard, J.M. and Lindsay, J.F., 1991, Sequence stratigraphy of the latest Proterozoic-Cambrian Pertaoorta Group, northern Amadeus Basin, central Australia: BMR Bulletin 236, pp. 171-194.

Kennard, J.M. and Nicoll, R.S., 1986, Late Proterozoic and early Palaeozoic depositional facies of the northern Amadeus Basin, central Australia. $12^{\text {th }}$ International Sedimentological Congress Field Excursion 25B: Bureau of Mineral Resources, Geology and Geophysics. Canberra.

Kennedy, M., 1993, The Undoolya Sequence: Late Proterozoic salt influenced deposition, Amadeus Basin, central Australia: Australian Journal of Earth Sciences, v. 40, pp. 217-228.

Korsch, R.J. and Lindsay, J.F., 1989, Relationships between deformation and basin evolution in the intracratonic Amadeus Basin, central Australia: Tectonophysics, v.158, pp. 5-22.

Lally, J.H. and Bajwah, Z.U., 2006. Uranium deposits of the Northern Territory: Northern Territory Geological Survey, Report 20.

Lindsay, J.F., 1987, Sequence stratigraphy and depositional controls on the Late Proterozoic-Early Cambrian sediments of the Amadeus Basin, central Australia: AAPG Bulletin 71, pp. 1387-1403.

Lindsay, J.F., 1989, Depositional controls on glacial facies associations in a 
basinal setting, Late Proterozoic, Amadeus Basin, central Australia: Palaeogeography, Palaeoclimatology, Palaeoecology, v. 73, pp. 205-232.

Lindsay, J.F. (ed), 1993, Geological atlas of the Amadeus Basin: Bureau of Mineral Resources, Australia, Canberra.

Lindsay, J.F., 1999, Heavitree Quartzite, a Neoproterozoic (ca 800-760 Ma), high energy, tidally influenced ramp association, Amadeus Basin, central Australia: Australian Journal of Earth Sciences, v. 46, pp. 127-139.

Lindsay, J.F. and Korsch, R.J., 1991, The evolution of the Amadeus Basin, central Australia: Bureau of Mineral Resources, Geology and Geophysics, Bulletin 236, pp. 7-32.

Maidment, D.W., Williams, I.S. and Hand, M., 2007, Testing long-term patterns of basin sedimentation by detrital zircon geochronology, Centralian Superbasin, Australia: Basin Research, v. 19, pp. 335-360.

Marshall, T.R., 2004, Review of the source rocks in the Amadeus Basin: Northern Territory Geological Survey, Record 2004-008.

Marshall, T.R, and Dyson, I.A., 2007, Halotectonics - a key element of Amadeus Basin development and prospectivity, in Munson, T.J. and Ambrose, G.J. (eds), Proceedings of the Central Australian Basins Symposium (CABS), Alice Springs, Northern Territory, 16-18 August, 2005: Northern Territory Geological Survey, Special Publication 2, pp. $136-146$.

Marshall, T.R., Dyson, I.A. and Liu, K., 2007, Petroleum systems in the Amadeus Basin, central Australia: Were they all oil prone? in Munson, T.J. and Ambrose, G.J. (eds), Proceedings of the Central Australian Basins Symposium(CABS), Alice Springs, $16-18^{\text {th }}$ August, 2005: Northern Territory Geological Survey, Special Publication 2.

Mawby, J., Hand, M., Foden, J. and Kinny, P., 1998, Ordovician granulites in the southeastern Arunta Inlier: a new twist in the Palaeozoic History of Central Australia: Geological Society of Australia, Abstracts 49, p. 296.

Mawby, J., Hand, M. and Foden, J., 1999, Sm-Nd evidence for high grade Ordovician metamorphism in the Arunta Block, central Australia: Journal of Metamorphic Geology, v. 17, pp. 653-668.

Munroe. S, Ham, A. and Griffin, S., 2004, Amadeus Basin SEEBASE ${ }^{\mathrm{TM}}$ Project. September 2004: Northern Territory Geological Survey, Record 2004-010.

Nicoll, R.S., Owen, M., Shergold, J.H., Laurie, J.R. and Gorter, J.D., 1988, Ordovician event stratigraphy and the development of a Larapintine Seaway, central Australia, in BMR 89, yearbook of the Bureau of Mineral Resources, Geology and Geophysics: Geoscientific research, resource assessment, and database development, 1 July 1988 to 30 June 1989: Bureau of Mineral Resources, Australia, Canberra, pp. 52-53.

Priess, W.V., Walter, M.R., Coats, R.P. and Wells, A.T., 1978, Lithological correlations of Adelaidean glaciogenic rocks in parts of the Amadeus, Ngalia and Georgina Basins: BMR Journal of Australian Geology and Geophysics, v. 3, pp. 45-53.

Pritchard, C.E. and Quinlan, T., 1962, The geology of the southern half of the Hermannsburg 1:250,000 sheet: Bureau of Mineral Resources, Report 61.

Scrimgeour, I.R. and Close, D., 1999, Regional high pressure metamorphism during intracratonic deformation: the Petermann Orogeny, central Australia: Journal of Metamorphic Geology, v. 17, pp. 557-572.

Scrimgeour, I.R., Close, D.F. and Edgoose, C.J., 1999, Petermann Ranges Northern Territory, 1:250,000 geological series explanatory notes (Second
Edition). SG 52-7: Northern Territory Geological Survey, Darwin.

Shaw, R.D., 1991, The tectonic development of the Amadeus Basin, central Australia: Bureau of Mineral Resources, Bulletin 236, pp. 429-462.

Shaw, R.D., Korsch, R.J., Wright, C. and Goleby, B.R., 1991, Seismic interpretation and thrust tectonics of the Amadeus Basin, central Australia, along the BMR regional seismic line: Bureau of Mineral Resources, Bulletin 236, pp. 385-408.

Shergold, J.H., 1986, Review of the Cambrian and Ordovician palaeontology of the Amadeus Basin, central Australia: Bureau of Mineral Resources, Geology and Geophysics, Report 276.

Shergold, J.H., Elphinstone, R., Laurie, J.R., Nicoll, R.S., Walter, M.R., Young, G.C. and Zang, W., 1991, Late Proterozoic and early Palaeozoic palaeontology and biostratigraphy of the Amadeus Basin: Bureau of Mineral Resources, Bulletin 236, pp. 97-112.

Veevers, J.J., 1976, Early Phanerozoic events on and alongside the Australasian-Antarctic Platform: Journal of the Geological Society of Australia, v. 23, pp. 183-206.

Walley, A.M., Cook, P.J., Bradshaw, J., Brakel, A.T., Kennard, J.M., Lindsay, J.F., Nicoll, R.S., Olissoff, S., Owen, M., Shergold, J.H., Totterdell, J.M. and Young, G.C., 1991, The Palaeozoic palaeogeography of the Amadeus Basin region: Bureau of Mineral Resources, Bulletin 236, pp. 155-169.

Walter, M.R. and Veevers, J.J., 2000, Neoproterozoic Australia, in Veevers, J.J. (ed), Billion-year history of Australia and neighbours in Gondwanaland: GEMOC Press, Sydney.

Walter, M.R., Veevers, J.J., Calver, C.R. and Grey, K., 1995, Neoproterozoic stratigraphy of the Centralian Superbasin, Australia: Precambrian Research, v. 73, pp. 173-195.

Wells, A.T., Forman, D.J., Ranford, L.C. and Cook, P.J., 1970, Geology of the Amadeus Basin, central Australia: Bureau of Mineral Resources, Bulletin 100.

Williams, G.K., Hopkins, R.M. and McNaughton, D.A., 1965, Pacoota reservoir rocks, Amadeus basin, NT, Australia: The APEA Journal, v. 5, pp. $159-167$.

Young, G.C., 1974, Stratigraphic occurrence of some placoderm fishes in the Middle and Late Devonian. Newsletters in Stratigraphy, v. 3, pp. 243261

Young, G.C., 1985, New discoveries of Devonian vertebrates from the Amadeus Basin, central Australia: BMR Journal of Australian Geology and Geophysics, v. 9, pp. 239-254.

Young, G.C., 1988, New occurrences of phllolepud placoderms from the Devonian of central Australia: BMR Journal of Australian Geology and Geophysics, v. 10, pp. 363-376.

Young, G.C., 2005, An articulated phyllolepid fish (Placodermi) from the Devonian of central Australia: implications for non-marine connections with the Old Red Sandstone continent: Geological Magazine, v. 142, pp. $173-186$

Zhao, J.X., McCulloch, M.T. and Bennett, V.C., 1992, Sm-Nd and U-Pb zircon isotopic constraints on the provenance of sediments from the Amadeus Basin, central Australia: Evidence for REE fractionation: Geochimica et Cosmochimica Acta, v. 56, pp. 921-940.

Zhao, J.X., McCulloch, M.T. and Korsch, R.J., 1994, Characterisation of a plume-related $\sim 800$ Ma magmatic event and its implications for basin formation in central-southern Australia: Earth and Planetary Science Letters, v. 121, pp. 349-367.

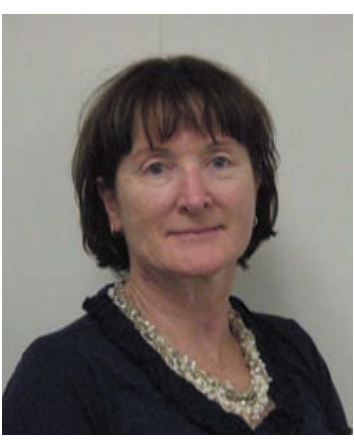

Chris Edgoose joined the Northern Territory Geological Survey in 1981, after completing a Bachelor of Science (Hons) majoring in geology at the University of Melbourne. Initially based in Darwin, she worked on the Paleoproterozoic Litchfield Province and Pine Creek Orogen until 1987. She then relocated to Alice Springs, and worked on the Paleo-Mesoproterozoic Musgrave Province and southern and central Arunta Regions. She has coauthored many maps and publications relating to all these basement terrains, as well as peer-reviewed papers. She is currently a project manager and senior regional geologist in Alice Springs. 